\title{
Secretagogue effects on intracellular calcium in pancreatic duct cells
}

\author{
Edward L. Stuenkel ${ }^{1}$ and Seth R. Hootman ${ }^{2}$ \\ 1 Department of Physiology, University of Michigan, 7744 Medical Sciences II Building, Ann Arbor MI 48109-0622, USA \\ 2 Department of Physiology, Michigan State University, East Lansing MI 48824, USA
}

Received September 29, 1989/Received after revision March 2/Accepted March 21, 1990

\begin{abstract}
Regulation of intracellular free calcium $\left(\left[\mathrm{Ca}^{2+}\right]_{\mathrm{i}}\right)$ in single epithelial duct cells of isolated rat and guinea pig pancreatic interlobular ducts by secretin, carbachol and cholecystokinin was studied by microspectrofluorometry using the $\mathrm{Ca}^{2+}$-sensitive, fluorescent probe Fura-2. Rat and guinea pig duct cells exhibited mean resting $\left[\mathrm{Ca}^{2+}\right]_{\mathrm{i}}$ of $84 \mathrm{nM}$ and $61 \mathrm{nM}$, respectively, which increased by $50 \%-100 \%$ in response to carbachol stimulation, thus demonstrating the presence of physiologically responsive cholinergic receptors in pancreatic ducts of both species. The carbachol-induced increase in $\left[\mathrm{Ca}^{2+}\right]_{\mathrm{i}}$ involved both mobilization of $\mathrm{Ca}^{2+}$ from intracellular stores and stimulation of influx of extracellular $\mathrm{Ca}^{2+}$. In contrast, neither cholecystokinin nor secretin showed reproducible or sizeable increses in $\left[\mathrm{Ca}^{2+}\right]_{i}$. Both rat and guinea pig duct cells showed considerable resting $\mathrm{Ca}^{2+}$ permeability. Lowering or raising the extracellular $\left[\mathrm{Ca}^{2+}\right]_{\mathrm{i}}$ led, respectively, to a decrease or increase in the resting $\left[\mathrm{Ca}^{2+}\right]_{\mathrm{i}}$. Application of $\mathrm{Mn}^{2+}$ resulted in a quenching of the fluorescence signal indicating its entry into the cell. The resting $\mathrm{Ca}^{2+}$ and $\mathrm{Mn}^{2+}$ permeability could be blocked by $\mathrm{La}^{3+}$ suggesting that it is mediated by a $\mathrm{Ca}^{2+}$ channel.
\end{abstract}

Key words: Pancreatic ducts - Intracellular calcium Carbachol - Secretin - Cholecystokinin - Acetylcholine - Bicarbonate secretion

\section{Introduction}

The exocrine pancreas secretes in response to hormonal and neurotransmitter stimulation an alkaline, $\mathrm{HCO}_{3}^{-}$rich, fluid containing a variety of digestive enzymes. This pancreatic juice is produced by the combined secretions of two functionally separate exocrine cell types, namely acinar and duct cells. Acinar cells secrete digestive enzymes along with a small volume of $\mathrm{NaCl}$-rich fluid and

Offprint requests to: $\mathrm{E}$. L. Stuenkel are stimulated primarily by acetylcholine and cholecystokinin (review: [21]). By contrast, the pancreatic ductal epithelium, which comprises less than $4 \%$ of the mass of pancreatic tissue, secretes a copious volume of fluid rich in $\mathrm{NaHCO}_{3}$ (reviews: $[8,28]$ ). The $\mathrm{HCO}_{3}^{-}$content and volume flow of the fluid produced by the ductal epithelium are stimulated 3- to 5-fold over the unstimulated state by the peptide hormone secretin. These effects of secretin are believed to be mediated by receptor-induced increases in intracellular cAMP, on the basis of measurements of cAMP content in secretin-stimulated isolated duct fragments $[1,2,12]$ and stimulation of $\mathrm{HCO}_{3}^{-}$secretion from perfused pancreas preparations following exogenous application of dibutyryl-cAMP [9]. In addition, a number of studies have suggested that the stimulatory effect of secretin is largely attributable to its actions on the smaller intra- and interlobular ducts [8].

The mechanisms utilized by duct cells to accomplish $\mathrm{HCO}_{3}^{-}$secretion have until the recent application of optical [29], electrophysiological [14] and combined electrical and perfusion techniques $[25,26]$ been largely unknown. However, results from these recent studies together with results from earlier pharmacological and ionic replacement studies $[8,28]$ have now provided evidence for the involvement of specific ion-transport mechanisms in the duct epithelium that are probably involved in the processes of $\mathrm{HCO}_{3}^{-}$and fluid secretion. These include $\mathrm{Na}^{+} / \mathrm{K}^{+}$-ATPase $[6,25]$ and $\mathrm{Na}^{+} / \mathrm{H}^{+}$exchange $[25,29]$ in the basolateral plasma membrane, an apical membrane $\mathrm{Cl}^{-} / \mathrm{HCO}_{3}^{-}$exchanger $[26,28]$ and apical $\mathrm{Cl}^{-}$selective channels $[14,15]$. Identification of these various transport pathways has led to the convergence of cellular models for duct cell $\mathrm{HCO}_{3}^{-}$secretion as presented in several recent papers [15, 26, 29].

While secretin has been clearly established as the principle mediator of pancreatic $\mathrm{HCO}_{3}^{-}$secretion, in some species acetylcholine $[5,18]$ and cholecystokinin $[5,19$, 31] have been found to potentiate the stimulatory effects of secretin. In the pancreatic acinar cell, $\mathrm{Ca}^{2+}$ has been conclusively identified as an important intracellular messenger for acetylcholine and cholecystokinin [21], al- 
though there is currently no evidence for its involvement in regulation of ductal $\mathrm{HCO}_{3}^{-}$secretion by these secretagogues or by secretin. The purpose of the present study was therefore to measure $\left[\mathrm{Ca}^{2+}\right]_{i}$ in duct cells by microspectrofluorometry using the $\mathrm{Ca}^{2+}$-sensitive, fluorescent probe, Fura-2 and to determine the effects of cholinergic agonists, cholecystokinin and secretin on the $\left[\mathrm{Ca}^{2+}\right]$. To this end isolated pancreatic duct fragments devoid of acinar cells were isolated from dispersed rat and guinea pig pancreases. These preparations retain normal tubular configuration and cellular orientation as previously described $[20,29]$. Results of this study show that the cholinergic agonist carbachol increases $\left[\mathrm{Ca}^{2+}\right]_{\mathrm{i}}$ in pancreatic duct cells of both species and that this increase in $\left[\mathrm{Ca}^{2+}\right]_{i}$ results from both a mobilization of $\mathrm{Ca}^{2+}$ from intracellular stores and stimulation of extracellular $\mathrm{Ca}^{2+}$ influx. By contrast, neither cholecystokinin nor secretin induced reproducible or sizeable changes in $\left[\mathrm{Ca}^{2+}\right]_{i}$. In addition, the duct cells were found to show a considerable $\mathrm{Ca}^{2+}$ permeability in the non-stimulated state.

\section{Material and methods}

Isolation of duct cells and loading with Fura-2. Pancreatic interlobular duct fragments were prepared from male Sprague-Dawley rats $(200-250 \mathrm{~g})$ or from guinea pigs $(250-300 \mathrm{~g})$ as previously described $[20,29]$. Only fragments less than $80 \mu \mathrm{m}$ in diameter were chosen for use in the present study. Isolated duct fragments were incubated with $1 \mu \mathrm{M}$ Fura-2 acetoxymethyl ester (AM) at $37^{\circ} \mathrm{C}$ in a physiological salt solution (PSS) for $20 \mathrm{~min}$. For rat fragments the PSS contained (in $\mathrm{mM}$ ): $\mathrm{NaCl} 137, \mathrm{MgCl}_{2} 0.57, \mathrm{KCl} 4.7, \mathrm{CaCl}_{2}$ 1.28, HEPES 10, glucose 10. This medium was supplemented with $0.5 \mathrm{mg} / \mathrm{ml}$ bovine serum albumin, $0.1 \mathrm{mg} / \mathrm{ml}$ soybean trypsin inhibitor, and Eagle's minimal essential medium amino acids, and was adjusted to $\mathrm{pH} 7.35$ with $\mathrm{NaOH}$. For guinea pig fragments, PSS consisted of (in mM): $\mathrm{NaCl} 118, \mathrm{MgCl}_{2} 1.1, \mathrm{KCl} 4.7, \mathrm{CaCl}_{2} 1.28$, $\mathrm{Na}_{2} \mathrm{HPO}_{4} 1.0$, HEPES 10 , and glucose 5.5 , supplemented with $1 \mathrm{mg}$ / $\mathrm{ml}$ bovine serum albumin, $0.1 \mathrm{mg} / \mathrm{ml}$ soybean trypsin inhibitor and Eagle's minimal essential medium amino acids and was adjusted to $\mathrm{pH} 7.35$ with $\mathrm{NaOH}$. Following this $20 \mathrm{~min}$ incubation duct fragments were rinsed three times with PSS to remove extracellular Fura-2 AM and were subsequently kept in PSS at room temperature in the dark until use. Solutions used during the fluorescence measurements contained (in $\mathrm{mM}$ ): $\mathrm{NaCl} 135, \mathrm{KCl} 5, \mathrm{CaSO}_{4} 1, \mathrm{MgSO}_{4}$ 1, HEPES 10 , glucose 10 , which was adjusted to $\mathrm{pH} 7.4$ with $\mathrm{NaOH}$. $\mathrm{Ca}$-free solutions were prepared by omitting the $\mathrm{CaSO}_{4}$ and adding $1 \mathrm{mM}$ EGTA. In addition, solutions containing lanthanum and manganese, which were added without eqimolar ionic replacement, contained the chloride salts of $\mathrm{Ca}$ and $\mathrm{Mg}$ to avoid salt precipitation. Bovine serum albumin was added to all solutions $(0.1 \%)$ that contained the peptide agonists cholecystokinin and secretin.

Fluorescence measurements. Measurements of $[\mathrm{Ca}]_{\mathrm{i}}$ were made on single or small groups of duct cells by selective placement of individual duct fragments onto a glass coverslip mounted in the bottom of a chamber, the surface of which was pretreated with Cell-Tak (Collaborative Research Inc., Bedford, MA, USA). Ducts placed in the chamber rapidly adhered to the glass coverslip on the chamber bottom. The chamber, as described previousiy [30], was regulated at $37^{\circ} \mathrm{C}$ and connected to a superfusion reservoir, which allowed passage of solution at a rate of $1 \mathrm{mi} / \mathrm{min}$ (chamber volume $100 \mu$ ) over the duct fragments and allowed application and removal of various solutions. The chamber was mounted on the stage of a Nikon Diaphot inverted microscope equipped with a $40 \times$ oil immersion epifluorescence lens (numerical aperture $=1.3$ ). The ductal cells selected were masked using a pinhole diaphragm stopped down to an optical diameter of $10 \mu \mathrm{m}$. The microscope was connected to a Spex Fluorolog spectrofluorometer system to generate alternating excitation wavelengths and for collection of the emitted photon counts via a photomultiplier tube. Excitation wavelengths of $340 \mathrm{~nm}$ and $380 \mathrm{~nm}$ were used. Emitted light passed through a $510 \pm 20-\mathrm{nm}$ barrier filter prior to photon counting. Photon counts were averaged over a 0.5 -s interval and stored by computer. The fluorescence ratio $(340 \mathrm{~nm} / 380 \mathrm{~nm})$ was calculated for each experiment after subtracting background autofluorescence (less than $8.5 \%$ of the signal at each wavelength) from each signal as measured on unloaded duct cells similarly mounted in the chamber. The fluorescence ratio was then converted to $\left[\mathrm{Ca}^{2+}\right]$, following an external standard calibration technique similar to that presented previously for parietal cells [24]. This technique measures the fluorescence of Fura-2 $(25 \mu \mathrm{M})$ in buffers of fixed $\left[\mathrm{Ca}^{2+}\right]$ placed in the experimental chamber without cells present. The calibration medium to which Fura-2 was added had the following composition (in $\mathrm{mM}$ ): $\mathrm{KCl}$ $120, \mathrm{NaCl} 10, \mathrm{MgCl}_{2}$ 1.2, EGTA 5, HEPES 10, adjusted to $\mathrm{pH} 7.4$ with $\mathrm{KOH}$. Calcium concentrations over the range of $40 \mathrm{pM}$ to $0.5 \mathrm{mM}$ were prepared by altering the $\mathrm{Ca}^{2+}:$ EGTA ratio. These measurements provided the $R_{\min }, R_{\max }$ and $F_{\mathrm{o}} / F_{\mathrm{s}}$ values of $0.8,18.62$ and 4.61 , respectively. The fluorescence ratio was then converted to $\left[\mathrm{Ca}^{2+}\right]$ using these values together with a $K_{d}$ of $225 \mathrm{nM}$ in the equation of Grynkiewicz et al. [17]. Visual observation showed that duct cells exhibited an even fluorescence throughout the cytoplasm. The enitted signal at $340 \mathrm{~nm}$ and $380 \mathrm{~nm}$ decreased only slightly over the 20-to-30-min recording period (see Fig. 5) indicating little photobleaching or Fura-2 dye leakage.

\section{Results}

\section{Effect of agonists on $\left[\mathrm{Ca}^{2+}\right]_{i}$}

The mean basal $\left[\mathrm{Ca}^{2+}\right]_{\mathrm{i}}$ calculated from Fura-2 fluorescence in rat and guinea pig pancreatic interlobular duct cells in HEPES-buffered NaCl saline was $84 \pm 4 \mathrm{nM}(n=$ 60 ; mean $\pm \mathrm{SE})$ and $61 \pm 4 \mathrm{nM}(n=31)$ respectively. Application of $10 \mu \mathrm{M}$ carbachol induced an increase in $\left[\mathrm{Ca}^{2+}\right]_{\mathrm{i}}$ in each rat and guinea pig duct cell tested. Representative fluorescence measurements of carbachol-induced changes in $\left[\mathrm{Ca}^{2+}\right]_{i}$ are shown in Fig. 1. The increase in $\left[\mathrm{Ca}^{2+}\right]_{i}$ induced by carbachol frequently $(63 \%$ of rat recordings) showed an initial peak followed by a decline towards a plateau value. Mean peak and plateau values for $10 \mu \mathrm{M}$ carbachol stimulation of rat duct cells were respectively $172 \pm 13 \mathrm{nM}(n=19)$ and $115 \pm 6 \mathrm{nM}(n=$ 12) while in guinea pig duct cells the values were some what lower averaging $94 \pm 8 \mathrm{nM}(n=19)$ and $88 \pm 7 \mathrm{nM}$ $(n=5)$. As shown in Fig. 1 A, $10 \mu \mathrm{M}$ carbachol induced a larger response than $1 \mu \mathrm{M}$ carbachol in the same duct cell. In each case a rapid return to basal $\left[\mathrm{Ca}^{2+}\right]_{i}$ values occurred on application of the muscarinic receptor antagonist atropine $(20 \mu \mathrm{M}$; Fig. 1B) or on removal of the agonist from the perfusing medium. In the latter case, restimulation with agonist demonstrated recovery of responsiveness.

By contrast, secretin application over the concentration range $10-100 \mathrm{nM}$ led to a change in basal $\left[\mathrm{Ca}^{2+}\right]_{\mathrm{i}}$ in only three of seven rat duct cells tested and in only one of eight guinea pig cells. Furthermore, the induced change in $\left[\mathrm{Ca}^{2+}\right]_{\mathrm{i}}$ in each case was quite small, averaging, for those responding, $17 \pm 5 \mathrm{nM}$ for rats and $9 \mathrm{nM}$ for the single guinea pig duct cell showing a response. Application of $10 \mathrm{nM}$ cholecystokinin likewise produced only a small change in basal $\left[\mathrm{Ca}^{2+}\right]_{\mathrm{i}}($ Fig. 1C, D). For this 

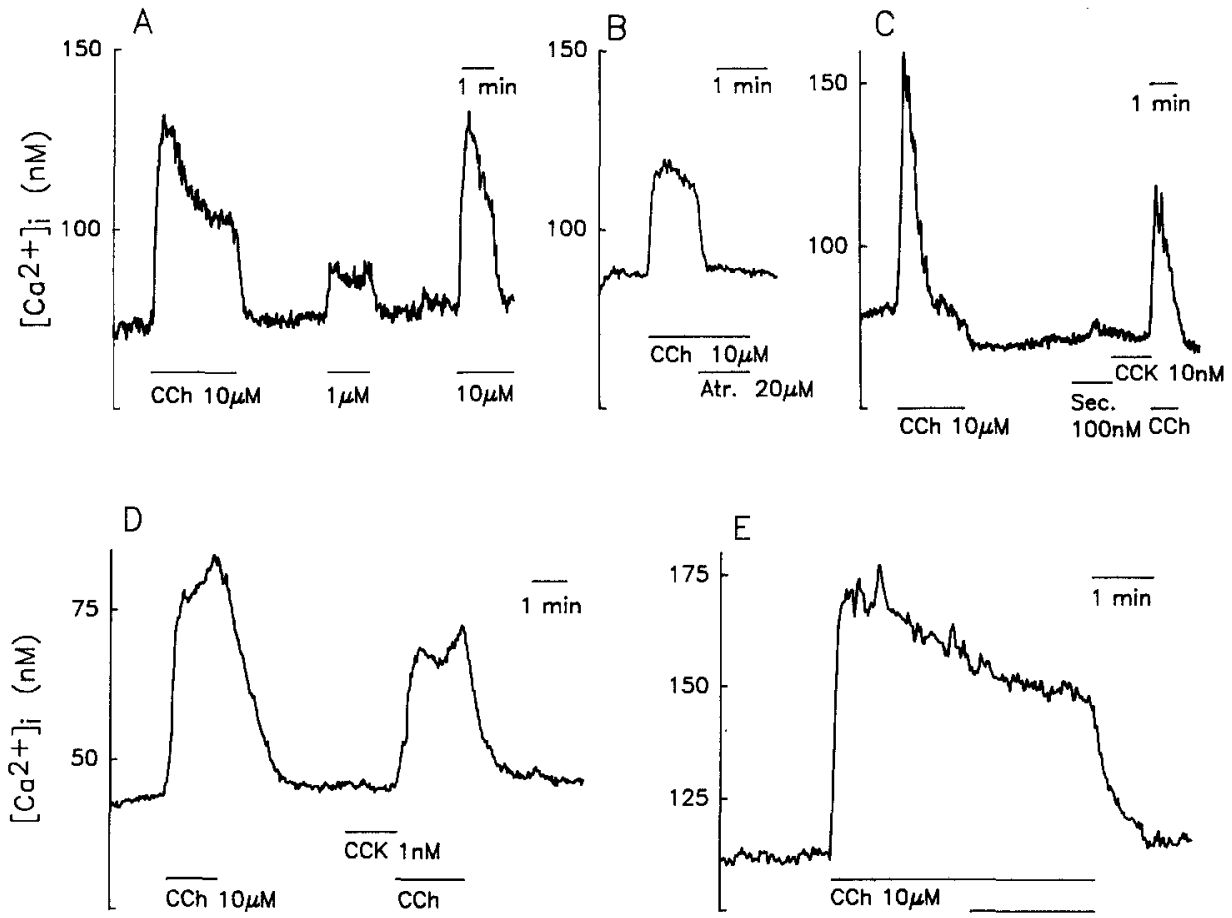

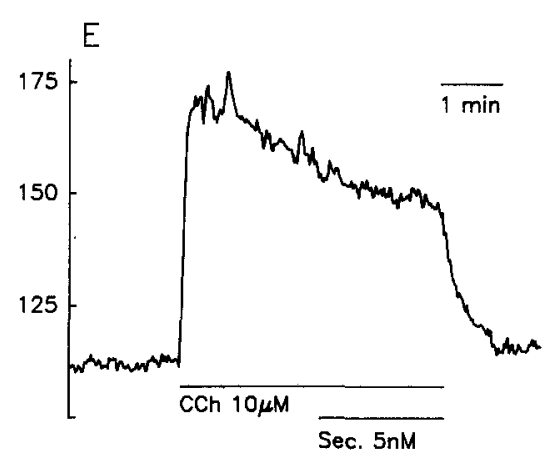

Fig. 1A-E. Effects of secretagogue stimulation on $\left[\mathrm{Ca}^{2+}\right]_{i}$ in isolated rat and guinea pig pancreatic interlobular duct cells. A Application of carbachol $(C C h)$ to rat duct cells induces an increase in $\left[\mathrm{Ca}^{2+}\right]_{i}$, which characteristically shows an initial peak followed by a sustained increase. Subsequent washout and restimulation with $\mathrm{CCh}$ at a lower concentration shows a reduced response. Restimulation with $10 \mu \mathrm{M}$ $\mathrm{CCh}$, following a recovery period, shows complete recovery as compared to the initial $\mathrm{CCh}$ application. B Application of atropine $(20 \mu \mathrm{M})$ during $\mathrm{CCh}$ $(10 \mu \mathrm{M})$ stimulation in rat duct cells results in a rapid decline from the stimulated rise in $\left[\mathrm{Ca}^{2+}\right]_{i}$ to prestimulation values. C Comparison of $\mathrm{CCh}$, secretin and cholecystokinin $(C C K)$ application on $\left[\mathrm{Ca}^{2+}\right]_{i}$ in rat duct cells and, in $\mathbf{D}$, on CCh and CCK on $\left[\mathrm{Ca}^{2+}\right]_{\text {i }}$ in guinea pig duct cells. E Failure of secretin to augment a $\mathrm{CCh}$-induced increase in $\left[\mathrm{Ca}^{2+}\right]_{\mathrm{i}}$ in rat pancreatic duct cells. Data shown are representative of at least three separate determinations agonist, six of nine rat duct cells responded with those six showing an average increase of $7 \pm 1 \mathrm{nM}$ while only two of ten guinea pigs ducts showed a response averaging $4 \mathrm{nM}$. Application of secretin subsequent or prior to a carbachol-induced increase in $\left[\mathrm{Ca}^{2+}\right]_{i}$ did not augment the effect of carbachol on $\left[\mathrm{Ca}^{2+}\right]_{i}$ (Fig. 1E).

\section{Effect of extracellular $\left[\mathrm{Ca}^{2+}\right]$ \\ on carbachol-induced responses}

Representative examples of the effect of extracellular $\left[\mathrm{Ca}^{2+}\right]$ on carbachol-induced changes in $\left[\mathrm{Ca}^{2+}\right]_{i}$ are shown in Fig. 2. There was a reduction in the basal $\left[\mathrm{Ca}^{2+}\right]_{\mathrm{i}}$ in each instance upon application of $\mathrm{Ca}^{2+}$-free medium. Nevertheless, in rat duct cells application of $10 \mu \mathrm{M}$ carbachol in the absence of extracellular $\mathrm{Ca}^{2+}$ (no medium $\mathrm{Ca}^{2+}$ plus $1 \mathrm{mM}$ EGTA) resulted in an increase in $\left[\mathrm{Ca}^{2+}\right]_{i}$. Mean basal and stimulated $\left[\mathrm{Ca}^{2+}\right]_{i}$ under $\mathrm{Ca}^{2+}$-free conditions in rat duct cells were $75 \pm 7 \mathrm{nM}$ $(n=6)$ and $119 \pm 14 \mathrm{nM}(n=6)$ respectively. Examination of the time course of the response, however, showed that in the absence of extracellular $\mathrm{Ca}^{2+}$ the response to carbachol was transient, returning to basal $\left[\mathrm{Ca}^{2+}\right]_{\mathrm{i}}$ values prior to removal of the agonist. These data suggest that in rat pancreatic duct cells agonist-induced increases in $\left[\mathrm{Ca}^{2+}\right]_{\mathrm{i}}$ are the result of two processes, release of $\mathrm{Ca}^{2+}$ from intracellular stores and an influx of extracellular $\mathrm{Ca}^{2+}$. Results qualitatively similar to those obtained for rat duct cells were also obtained in guinea pig ducts (Fig. $2 \mathrm{~B} ; n=4$ ) although guinea pigs showed lower basal $\left[\mathrm{Ca}^{2+}\right]_{i}$ values in $\mathrm{Ca}^{2+}$-free medium $(38 \pm 2 \mathrm{nM}, n=4)$ and a smaller increase $(26 \%)$ in $\left[\mathrm{Ca}^{2+}\right]_{i}$ on carbachol stimulation. This is consistent with the lower basal and stimulated $\left[\mathrm{Ca}^{2+}\right]_{\mathrm{i}}$ values for this species in the presence of extracellular $\mathrm{Ca}^{2+}$ as shown above.
Additional evidence for a component of carbacholinduced extracellular $\mathrm{Ca}^{2+}$ influx is shown in Fig. 3. Removal of extracellular $\mathrm{Ca}^{2+}$ during the plateau portion of a carbachol-induced increase in $\left[\mathrm{Ca}^{2+}\right]_{\mathrm{i}}$ resulted in a rapid decline below resting $\left[\mathrm{Ca}^{2+}\right]_{i}$, which was reversible on re-addition of extracellular $\mathrm{Ca}^{2+}$. Cadmium and lanthanum, inorganic blockers of $\mathrm{Ca}^{2+}$ channels, were also effective at reducing the plateau portion of a carbacholinduced increase in $\left[\mathrm{Ca}^{2+}\right]_{i}$ (Fig. 3 B, C). The blocking effect of $\mathrm{Cd}^{2+}$ during carbachol stimulation is reversible as demonstrated by a resurgent rise in $\left[\mathrm{Ca}^{2+}\right]_{\mathrm{i}}$ on $\mathrm{Cd}^{2+}$ removal $(n=3)$. However, an incomplete recovery to basal $\left[\mathrm{Ca}^{2+}\right]_{\mathrm{i}}$ occurred following washout of the agonist after $\mathrm{Cd}^{2+}$ treatment. The blockade of agonist-induced $\mathrm{Ca}^{2+}$ entry by $\mathrm{La}^{3+}$ was not reversible (see also below). Lanthanum did not interfere with the transient phase of a carbachol-induced increase in $\left[\mathrm{Ca}^{2+}\right]_{i}$, indicating that $\mathrm{La}^{3+}$ does not exert its effect via an antagonist action on muscarinic receptors (Fig. 3D). These results demonstrate that the carbachol-induced sustained increase in $\left[\mathrm{Ca}^{2+}\right]_{i}$ above basal results from agonist induced extracellular $\mathrm{Ca}^{2+}$ entry.

\section{Examination of resting $\mathrm{Ca}^{2+}$ permeability}

Most studies of $\mathrm{Ca}^{2+}$ signaling in non-excitable cells show little or no change in $\left[\mathrm{Ca}^{2+}\right]_{\mathrm{i}}$ on removal and replacement of extracellular $\mathrm{Ca}^{2+}$ in the absence of agonist. The measurable decrease in $\left[\mathrm{Ca}^{2+}\right]_{\mathrm{i}}$ observed on removal of extracellular $\mathrm{Ca}^{2+}$ in both rat and guinea pig duct cells led us to examine further the resting $\mathrm{Ca}^{2+}$ permeability of these cells. Figure $4 \mathrm{~A}$ shows that reduction of extracellular $\mathrm{Ca}^{2+}$ to $0.1 \mu \mathrm{M}\left(\mathrm{EGTA}: \mathrm{Ca}^{2+}=1.4\right)$, a concentration of free $\mathrm{Ca}^{2+}$ approximating that in the cytoplasm, reduces $\left[\mathrm{Ca}^{2+}\right]_{i}$ rapidly and to an extent similar to the 

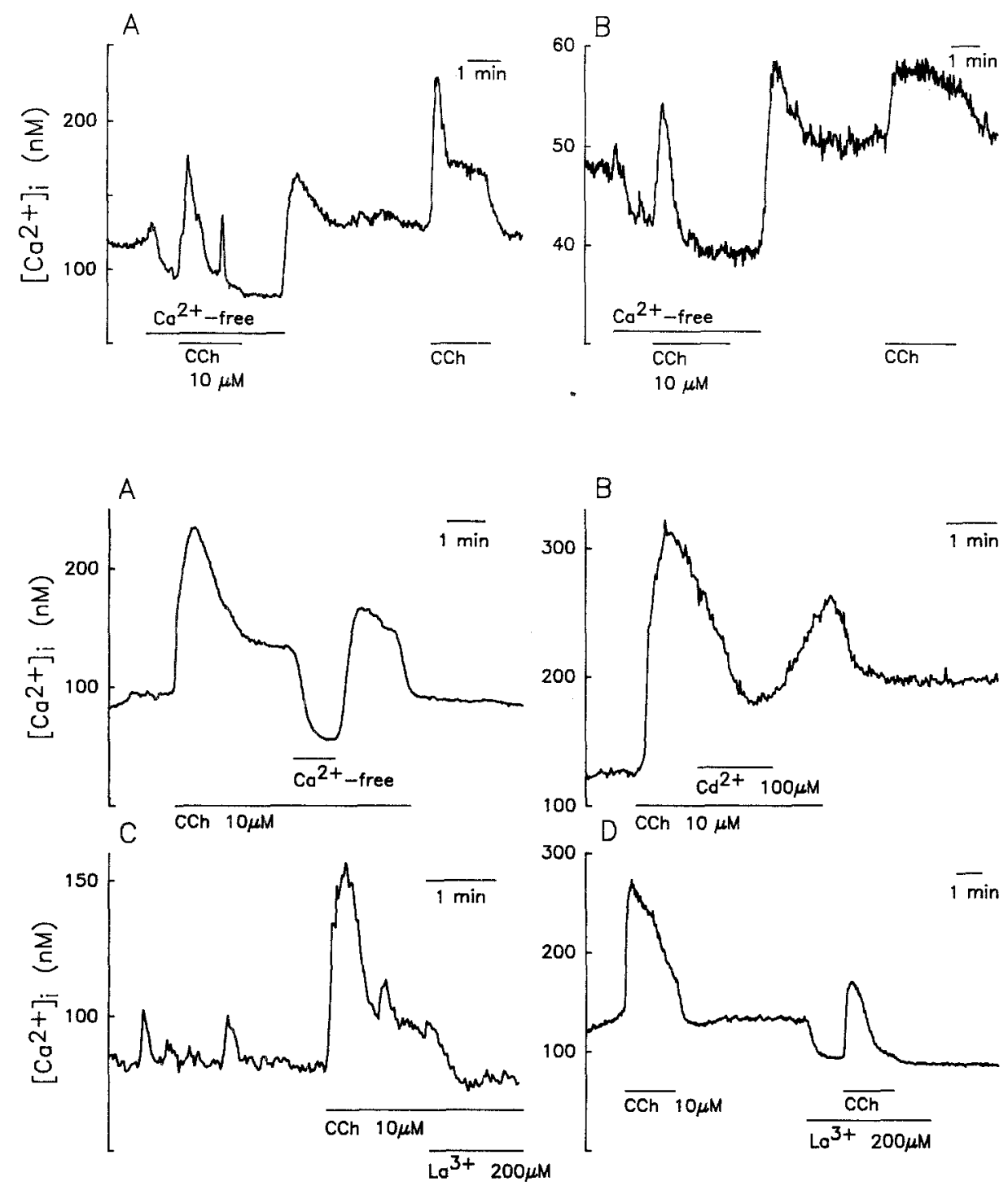

Fig. 2A, B. Effect of extracellular $\mathrm{Ca}^{2+}$ on $\mathrm{CCh}$-induced changes in $\left[\mathrm{Ca}^{2+}\right]_{i}$. Removal of extracellular $\mathrm{Ca}^{2+}$ prior and during $\mathrm{CCh}$ application is ineffective in eliminating the induced increase in $\left[\mathrm{Ca}^{2+}\right]_{\mathrm{i}}$ in rat $(\mathbf{A})$ and guinea pig (B) duct cells. $\left[\mathrm{Ca}^{2+}\right]_{\mathrm{i}}$ declines to basal levels during stimulation in the absence, but not in the presence, of extracellular $\mathrm{Ca}^{2+}$. Note the decline in basal $\left[\mathrm{Ca}^{2+}\right]_{\mathrm{i}}$ upon removal of extracellular $\mathrm{Ca}^{2+}$ and its recovery on replacement of medium $\mathrm{Ca}^{2+}$. Data are representative of three similar experiments
Fig. 3A-D. CCh-induced extracellular $\mathrm{Ca}^{2+}$ entry is reduced by medium lacking extracellular $\mathrm{Ca}^{2+}$ or containig inorganic $\mathrm{Ca}^{2+}$ channel blockers. A Extracellular $\mathrm{Ca}^{2+}$ removal during a sustained $\mathrm{CCh}$-induced increase in $\left[\mathrm{Ca}^{2+}\right]_{i}$ reduced $\left[\mathrm{Ca}^{2+}\right]_{\mathrm{i}}$ to below basal values, which is reversible on readmission of medium $\mathrm{Ca}^{2+}$. B Application of $\mathrm{Cd}^{2+}$ reduced, reversibly the $\mathrm{CCh}$-induced sustained increase in $\left[\mathrm{Ca}^{2+}\right]_{i}$. C Lanthanum application completely blocked CCh-induced extracellular $\mathrm{Ca}^{2+}$ entry. $\mathbf{D ~ L a}{ }^{3+}$ was ineffective in blocking a $\mathrm{CCh}$-induced transient increase in $\left[\mathrm{Ca}^{2+}\right]_{i}$ although the effect of $\mathrm{La}^{3+}$ to reduce resting $\left[\mathrm{Ca}^{2+}\right]_{\mathrm{i}}$ was irreversible. Data shown are from rat duct cells and representative of results from at least three experiments generation of an outwardly directed $\mathrm{Ca}^{2+}$ gradient by complete removal of extracellular $\mathrm{Ca}^{2+}(<100 \mathrm{pM})$. $\left[\mathrm{Ca}^{2+}\right]_{\mathrm{i}}$ levels declined by $27 \pm 5 \mathrm{nM}(n=9)$ following the change to $\mathrm{Ca}^{2+}$-free medium in cells that had received no prior treatment with carbachol. Replacement of extracellular $\mathrm{Ca}^{2+}$ following its reduction, especially following complete removal of $\mathrm{Ca}^{2+}$, led to an overshooting recovery averaging $36 \pm 9 \mathrm{nM}(n=9)$ above the initial basal value (see also Figs. 2 and 5) followed by relaxation towards the original basal $\left[\mathrm{Ca}^{2+}\right]_{\mathrm{i}}$ value. Application of $\mathrm{La}^{3+}$, previously shown to block agonist-induced extracellular $\mathrm{Ca}^{2+}$ influx, was also effective in rapidly reducing basal $\left[\mathrm{Ca}^{2+}\right]_{i}$ to levels observed under reduced extracellular $\left[\mathrm{Ca}^{2+}\right] .\left[\mathrm{Ca}^{2+}\right]_{\mathrm{i}}$ declined following treatment with $\mathrm{La}^{3+}$ by $25 \pm 4 \mathrm{nM}(n=6)$. The reduction in $\left[\mathrm{Ca}^{2+}\right]_{\mathrm{i}}$ in the presence of $\mathrm{La}^{3+}$, which presumably blocks only $\left[\mathrm{Ca}^{2+}\right]_{\mathrm{i}}$ entry, also suggests that duct cells possess relatively active intracellular $\mathrm{Ca}^{2+}$ sequestration or cellular $\mathrm{Ca}^{2+}$ extrusion mechanisms. Furthermore, the failure of atropine $(10 \mu \mathrm{M})$ to reduce the basal $\left[\mathrm{Ca}^{2+}\right]_{\mathrm{i}}$ (Fig. $4 \mathrm{~B}$ ) suggests that the high $\mathrm{Ca}^{2+}$ permeability of these cells is not the result of residual activation by acetylcholine re- lease from adherent nerve terminals on the duct fragments.

In agreement with results showing a measurable resting $\mathrm{Ca}^{2+}$ permeability, increasing the extracellular $\left[\mathrm{Ca}^{2+}\right]$ from $1 \mathrm{mM}$ to $5 \mathrm{mM}$ resulted in an increase in $\left[\mathrm{Ca}^{2+}\right]_{i}$ (Fig. 4B). The increase in $\left[\mathrm{Ca}^{2+}\right]_{i}$ on raising the extracellular $\left[\mathrm{Ca}^{2+}\right]$ could be totally blocked by pretreatment with $\mathrm{La}^{3+}$ (Fig. 4C; $n=8$ ). Similarly, recovery of $\left[\mathrm{Ca}^{2+}\right]_{\mathrm{i}}$ following treatment with medium lacking $\mathrm{Ca}^{2+}$ (no added $\mathrm{Ca}^{2+}$ or EGTA) and subsequent $\mathrm{Ca}^{2+}$ readdition was blocked by $\mathrm{La}^{3+}$ pretreatment $(n=3)$. The high resting $\mathrm{Ca}^{2+}$ permeability was similar in both bicarbonate-buffered $(25 \mathrm{mM})$ and HEPES-buffered media (Fig. 4D; $n=4$ ).

In several non-excitable cell types receptor-operated $\mathrm{Ca}^{2+}$-influx pathways show permeability to $\mathrm{Mn}^{2+}$ as well as $\mathrm{Ca}^{2+}$. $\mathrm{Mn}^{2+}$ influx into the cytoplasm across the plasma membrane can be discerned in dye-loaded cells by its quenching of Fura-2 fluorescence. In most cases, rapid quenching occurs only during agonist stimulation or under conditions where the intracellular agonist-sensitive pool has been depleted and refilling is occurring [22, 

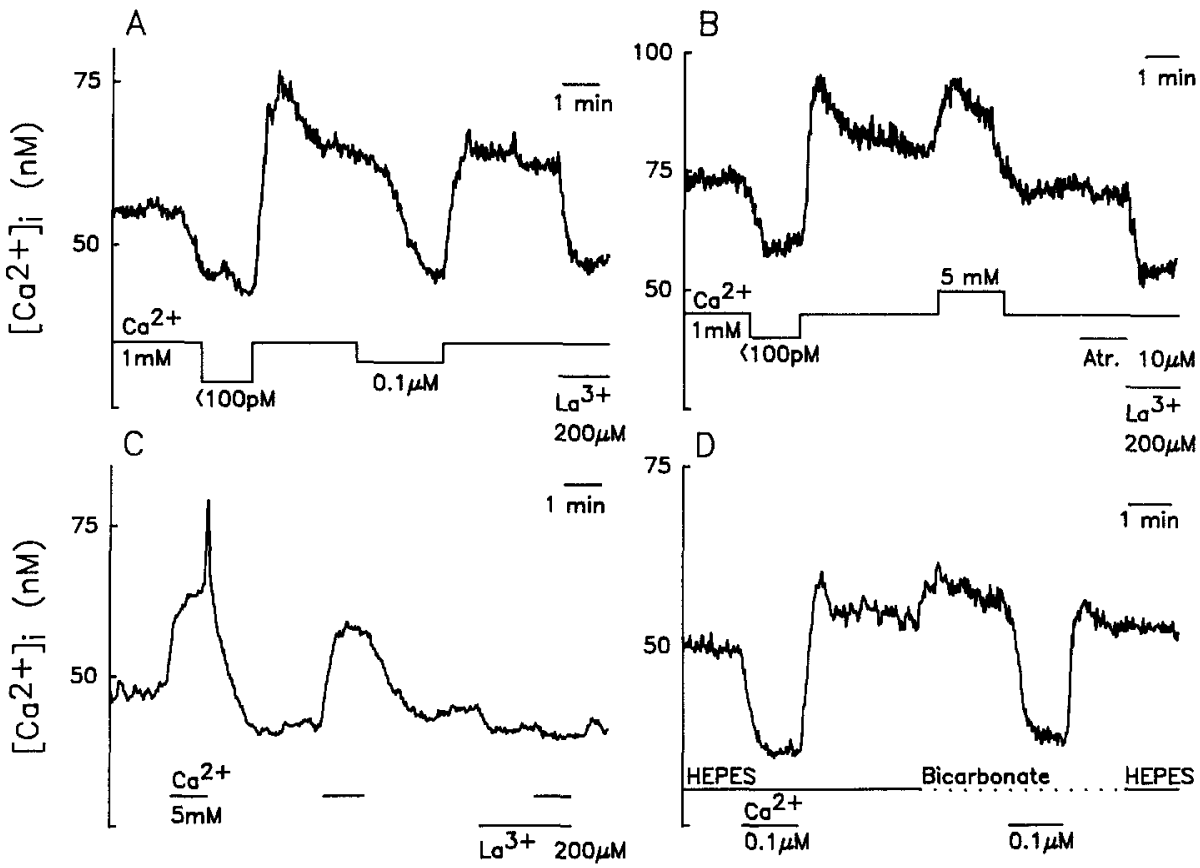

Fig. 4A-D. Effect of extracellular $\mathrm{Ca}^{2+}$ and $\mathrm{La}^{3+}$ on resting $\left[\mathrm{Ca}^{2+}\right]_{\mathrm{i}}$ in rat pancreatic duct cells. A Lowering extracellular $\left[\mathrm{Ca}^{2+}\right]$ to $<100 \mathrm{pM}$ or to $0.1 \mu \mathrm{M}$ reduced resting $\left[\mathrm{Ca}^{2+}\right]_{i}$, which recovered to preapplication values following readmission of medium $\mathrm{Ca}^{2+}$ $(1 \mathrm{mM})$. Note the overshoot on replacement of extracellular $\mathrm{Ca}^{2+} \cdot \mathrm{La}^{3+}$ also reduced $\left[\mathrm{Ca}^{2+}\right]_{\mathrm{i}}$ to a value similar to that observed under lowered external $\left[\mathrm{Ca}^{2+}\right]$. B Increasing the extracellular $\left[\mathrm{Ca}^{2+}\right]$ to $5 \mathrm{mM}$ increased the resting $\left[\mathrm{Ca}^{2+}\right]_{\mathrm{i}}$. Atropine had no effect on resting $\left[\mathrm{Ca}^{2+}\right]_{\mathbf{i}}$ while subsequent application of $\mathrm{La}^{3+}$ reduced $\left[\mathrm{Ca}^{2+}\right]_{i}$ to a level similar to that produced by lowering external $\left[\mathrm{Ca}^{2+}\right]$. C The induced rise in $\left[\mathrm{Ca}^{2+}\right]_{i}$ on raising extracellular $\left[\mathrm{Ca}^{2+}\right]$ is blocked by pretreatment with $\mathrm{La}^{3+}$. D Resting $\mathrm{Ca}^{2+}$ permeability is similar in both bicarbonate $(25 \mathrm{mM})$ and HEPES-buffered media. Data are representative of at least three experiments

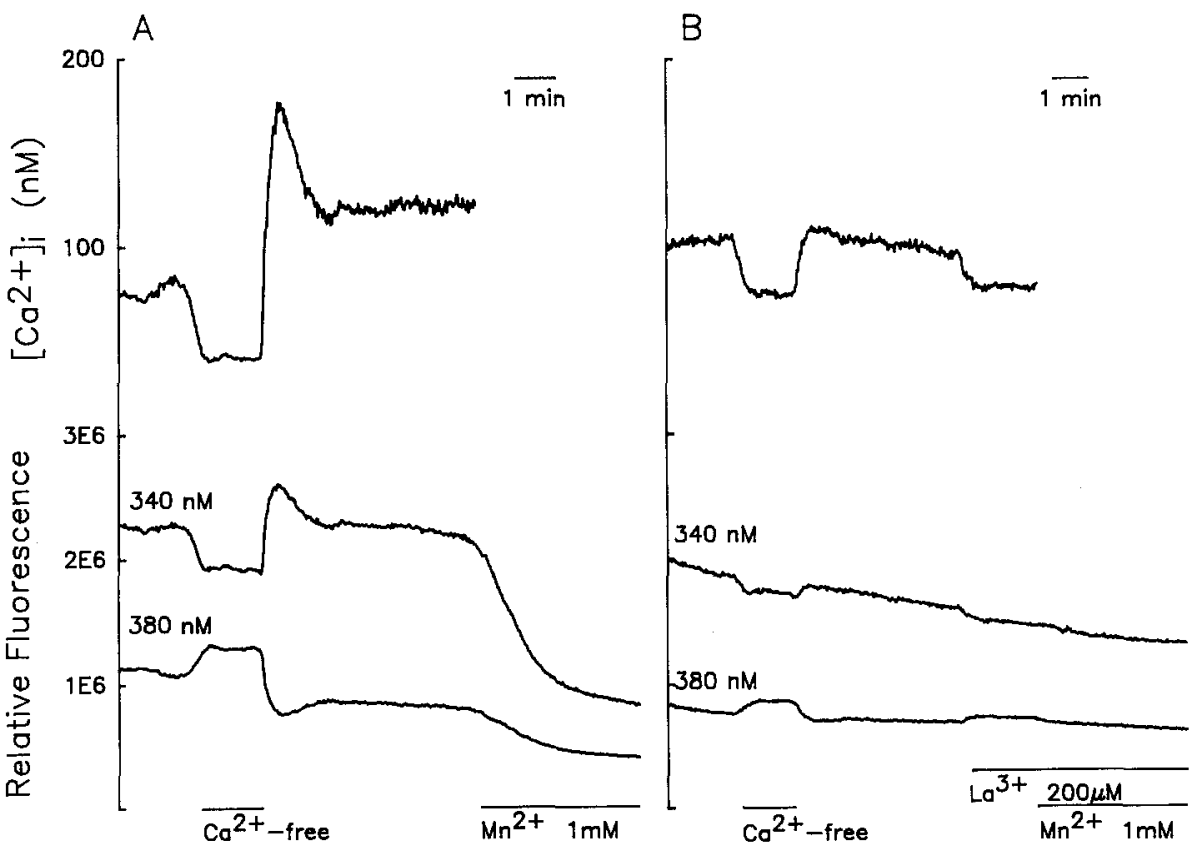

Fig. 5A, B. Effect of $\mathrm{Mn}^{2+}$ on Fura-2 fluorescence in rat pancreatic duct cells. A, B Upper, fluorescence ratio; lower, raw Fura-2 fluorescence intensity at $340 \mathrm{~nm}$ and $380 \mathrm{~nm}$. Mn application induced quenching of the fluorescence signal in $\mathbf{A}$, which in $\mathbf{B}$, is blocked by preaddition of $\mathrm{La}^{3+}$. Initial response to removal and replacement of extracellular $\mathrm{Ca}^{2+}$ reduced $\left[\mathrm{Ca}^{2+}\right]_{i}$, substantiating resting $\mathrm{Ca}^{2+}$ permeability of cells tested. Data are representative of at least three separate determinations
23]. Figure 5 shows the effects of $\mathrm{Mn}^{2+}(1 \mathrm{mM})$ treatment on the raw fluorescence intensity traces at $340 \mathrm{~nm}$ and $380 \mathrm{~nm}$ excitation of rat pancreatic duct cells. Initially each cell was tested for responsiveness to extracellular $\mathrm{Ca}^{2+}$ removal and subsequently, following reintroduction of extracellular $\mathrm{Ca}^{2+}$ and recovery, to $\mathrm{Mn}^{2+}$ permeability. Introduction of $\mathrm{Mn}^{2+}$ caused a rapid quenching of the fluorescence intensity traces (Fig. 5A). Manganese entry (and hence quenching of the fluorescent signals (could, however, be prevented by pre-addition with the $\mathrm{Ca}^{2+}$-channel blocker $\mathrm{La}^{3+}$ (Fig. 5B). These results further substantiate the observation that pancreatic duct cell plasma membranes exhibit significant di- valent cation permeability in the absence of agonist. This influx pathway is permeable to $\mathrm{Mn}^{2+}$ but can be blocked by $\mathrm{La}^{3+}$. The failure of $\mathrm{Mn}^{2+}$ to quench the fluorescent signal in the presence of $\mathrm{La}^{3+}$ suggests that these results cannot be explained by Fura-2 trapped in the lumens of the duct fragments that is reacting to changes in the extracellular $\left[\mathrm{Ca}^{2+}\right]$.

\section{Discussion}

Monitoring of $\left[\mathrm{Ca}^{2+}\right]_{\mathrm{i}}$ in single or small groups of pancreatic duct cells in the present work using the $\mathrm{Ca}^{2+}$-sensitive 
fluorescent probe Fura-2 has provided clear evidence for the presence of ductal muscarinic acetylcholine receptors in both rat and guinea pig, which upon agonist binding mobilize intracellular $\mathrm{Ca}^{2+}$ and elicit a sustained influx of extracellular $\mathrm{Ca}^{2+}$. Data presented here thus provide the first evidence for a direct stimulation of pancreatic duct cells by acetylcholine [8, 28]. Previously, the observed potentiating effects of nerve stimulation or of acetylcholine application on secretin-stimulated pancreatic secretion were often attributed to indirect effects, such as modified blood flow, rather than direct effects on the duct cells themselves. This concept arose, for example, from studies that showed that direct vagal stimulation alone in the cat and dog evoked little or no pancreatic $\mathrm{HCO}_{3}^{-}$ secretion, although $\mathrm{HCO}_{3}^{-}$secretion induced by secretin was potentiated by vagal stimulation $[5,18]$. In addition, gastric distension, which stimulates gastropancreatic reflexes and thus acetylcholine release and pancreatic enzyme secretion, had little effect on pancreatic bicarbonate secretion in cats, dogs and humans $[4,7,10]$. By contrast, our observation of carbachol-induced changes in $\left[\mathrm{Ca}^{2+}\right]_{i}$ in duct cells demonstrates a direct effect. The failure of acetylcholine alone to induce measurable $\mathrm{HCO}_{3}^{-}$secretion in previous studies suggests that the increase in duct cell $\left[\mathrm{Ca}^{2+}\right]_{\mathrm{i}}$ may, by itself, be an insufficient stimulus for $\mathrm{HCO}_{3}^{-}$and fluid secretion. It should be noted that the 1.5-to-2-fold change in $\left[\mathrm{Ca}^{2+}\right]_{\mathrm{i}}$ on carbachol $(10 \mathrm{mM})$ stimulation in duct cells is much less than the approximately 5-fold change observed in rat pancreatic acinar cells. The ability of carbachol to induce mobilization of $\mathrm{Ca}^{2+}$ from intracellular stores in pancreatic duct cells suggests, however, by analogy with acinar cells and other cell types [3], that acetylcholine binding to its receptor induces hydrolysis of phosphatidylinositol bisphosphate and the generation of inositol 1,4,5trisphosphate and diacylglycerol, the former of which may act to release $\mathrm{Ca}^{2+}$. The co-generation during this hydrolysis of diacylglycerol, an activator of protein kinase $\mathrm{C}$, further suggests that this kinase may also play a role in the potentiation of $\mathrm{HCO}_{3}^{-}$secretion. Potential sites of action include apical $\mathrm{Cl}^{-}$channels and $\mathrm{Na}^{+} / \mathrm{H}^{+}$ exchangers, which are found in duct cells and which in a number of cell types are regulated by changes in $\left[\mathrm{Ca}^{2+}\right]_{i}$ or protein-kinase-C-mediated phosphorylation $[13,16]$. These findings do not, however, exclude indirect effects of acetylcholine on ductal $\mathrm{HCO}_{3}^{-}$secretion.

The effects of secretin, the major secretagagoue of $\mathrm{HCO}_{3}^{-}$and fluid secretion from pancreatic ducts [8], and of cholecystokinin on $\left[\mathrm{Ca}^{2+}\right]_{i}$ were less clear. Although both hormones occasionally caused small changes in $\left[\mathrm{Ca}^{2+}\right]_{\mathrm{i}}$ their low frequency of occurrence and the size of the induced responses suggest that neither secretin nor cholecystokinin acts physiologically to evoke receptormediated changes in $\left[\mathrm{Ca}^{2+}\right]_{\mathrm{i}}$. The lack of effect of secretin on $\left[\mathrm{Ca}^{2+}\right]_{\mathrm{i}}$ is not surprising since numerous investigations have demonstrated that secretin's stimulation of ductal $\mathrm{HCO}_{3}^{-}$and fluid secretion and induction of apical membrane $\mathrm{Cl}^{-}$channel activity in duct cells can be reproduced by exogenously applied dibutyryl-cAMP or by other experimental paradigms that increase the intracellular cAMP concentration $[8,14,15,28]$. The lack of a reproducible effect of cholecystokinin on $\left[\mathrm{Ca}^{2+}\right]_{\mathrm{i}}$ in this study substantiates earlier studies that showed that it did not stimulate secretion from an in vivo rat pancreatic duct model where acinar cells had been selectively destroyed [11] and that caerulein, a stable cholecystokinin analog, did not stimulate fluid secretion from isolated rat duct fragments in culture [1]. The lack of an effect of cholecystokinin on $\left[\mathrm{Ca}^{2+}\right]_{i}$ in guinea pig ducts is somewhat surprising since it causes secretion of a bicarbonaterich juice from the guinea pig pancreas [27].

An additional observation in the present study is that pancreatic duct cells have a considerable resting $\mathrm{Ca}^{2+}$ permeability. The demonstration of this resting $\mathrm{Ca}^{2+}$ permeability in duct cells of both rat and guinea pig preparations, which are isolated using somewhat different protocols, argues against this characteristic of $\mathrm{Ca}^{2+}$ permeability being a result of the procedure utilized to prepare the ducts. Pancreatic acini, which are prepared in an identical fashion, do not exhibit changes in $\left[\mathrm{Ca}^{2+}\right]_{\mathbf{i}}$ in response to changes in extracellular $\left[\mathrm{Ca}^{2+}\right]$ under nonstimulating conditions [30] (unpublished observations). Furthermore, the resting $\mathrm{Ca}^{2+}$ permeability in duct cells appears to occur through a specific transport mechanism, since $\mathrm{La}^{3+}$, an inorganic $\mathrm{Ca}^{2+}$ channel antagonist, effectively blocks the $\mathrm{Ca}^{2+}$ permeability without itself entering the cell. The $\mathrm{Ca}^{2+}$ permeability pathway resembles in its ability both to pass $\mathrm{Mn}^{2+}$ and to be blocked by external $\mathrm{La}^{3+}$, a receptor-operated $\mathrm{Ca}^{2+}$ channel described in platelets and neutrophils but absent in some other non-excitable cell types such as parotid cells [22, 23]. In platelets and neutrophils, however, only slight quenching of Fura-2 fluorescence occurs under nonstimulated conditions, whereas in duct cells significant permeability exists. The possibility that residual activation of duct cells by acetylcholine release from nerve endings adhering to the isolated duct fragments was occurring was ruled out by the failure of atropine to reduce $\left[\mathrm{Ca}^{2+}\right]_{\mathrm{i}}$. The rapid drop in basal $\left[\mathrm{Ca}^{2+}\right]_{\mathrm{i}}$ under reduced $\mathrm{Ca}^{2+}$ conditions in the presence of $\mathrm{La}^{3+}$ suggests that resting $\left[\mathrm{Ca}^{2+}\right]_{\mathrm{i}}$ in the duct cell is determined by a balance between considerable resting $\mathrm{Ca}^{2+}$ influx and the activity of $\mathrm{Ca}^{2+}$ extrusion mechanisms. The physiological significance of such a resting $\mathrm{Ca}^{2+}$ permeability is unknown at present.

Acknowledgements. This work was supported by NIH grants DK41122 , DK-39853 and pilot project funds from the University of Michigan GI Peptide Center (DK-34933).

\section{References}

1. Argent BE, Arkle S, Cullen MJ, Green R (1986) Morphological, biochemical and secretory studies on rat pancreatic ducts maintained in tissue culture. J Exp Physiol 71:633-648

2. Arkle S, Lee CM, Cullen MJ Argent BE (1986) Isolation of ducts from the pancreas of copper-deficient rats. J Exp Physiol $71: 249-265$

3. Berridge MJ, Irvine RF (1984) Inositol trisphosphate, a novel second messenger in cellular signal transduction. Nature 312:315-321

4. Blair EL, Brown JC, Harper AA, Scratcherd T (1966) A gastric phase of pancreatic secretion. J Physiol (Lond) 184:812-824 
5. Brown JC, Harper AA, Scratcherd T (1967) Potentiation of secretin stimulation of the pancreas. J Physiol (Lond) 190:519530

6. Bundgaard M, Moller M, Poulsen JH (1981) Localisation of sodium pump sites in cat pancreas, J Physiol (Lond) 313:404414

7. Cargill JM, Wormsley KG (1979) Effect of gastric distension on human pancreatic secretion. Acta Hepato-Gastroenterol $26: 235-238$

8. Case RM, Argent BE (1986) Bicarbonate secretion by pancreatic duct cells: Mechanisms and control. In: Go VLW et al. (eds) The exocrine pancreas: biology, pathobiology and diseases. Raven Press, New York, pp 213-243

9. Case RM, Scratcherd T (1972) The actions of dibutyryl cyclic adenosine $3^{\prime}, 5^{\prime}$-monophosphate and methyl xanthines on pancreatic exocrine secretion. J Physiol (Lond) 223:649-667

10. Debas HI, Yamagishi $T$ (1978) Evidence for pyloropancreatic reflex for pancreatic exocrine secretion. Am J Physiol 234:E468-E471

11. Folsch UR, Creutzfeldt W (1977) Pancreatic duct cells in rats: secretory studies in response to secretin, cholecystokininpancreozymin, and gastrin. Gastroenterology 73:1053-1059

12. Folsch UR, Fischer H, Soling HD, Creutzfeldt W (1980) Effects of gastrointestinal hormones and carbamylcholine on cAMP accumulation in isolated pancreatic duct fragments from the rat. Digestion 20:277-292

13. Frizzell RA, Halm DR, Rechkemmer G, Shoemaker RL (1986) Chloride channel regulation in secretory epithelia. Fed Proc 45:2727-2731

14. Gray MA, Greenwell JR, Argent BE (1988) Secretin-regulated chloride channel on the apical plasma membrane of pancreatic duct cells. J Membr Biol 105:131-142

15. Gray MA, Harris A, Coleman L, Greenwell JR, Argent BE (1989) Two types of chloride channel on duct cells cultured from human fetal pancreas. Am J Physiol 257:C240-C251

16. Grinstein S, Rothstein A (1986) Mechanisms of regulation of the $\mathrm{Na}^{+} / \mathrm{H}^{+}$exchanger. J Membr Biol 90:1-12

17. Grynkiewicz G, Poenie M, Tsien RY (1985) A new generation of $\mathrm{Ca}^{2+}$ indicators with greatly improved fluorescence properties. J Biol Chem 260:3440 - 3450

18. Guzman S, Chayvialle JA, Banks WA, Rayford PL, Thompson JC (1979) Effect of vagal stimulation on pancreatic secretion and on blood levels of gastrin, cholecystokinin, secretin, vasoactive intestinal peptide, and somatostatin. Surgery $86: 329-336$
19. Henriksen FW, Worning $H$ (1967) The interaction of secretin and pancreozymin on the external pancreatic secretion in dogs. Acta Physiol Scand 70:241-249

20. Hootman SR, Logsdon CD (1988) Isolation and monolayer culture of guinea pig pancreatic duct epithelial cells. In Vitro Cell Dev Biol 24:566-574

21. Hootman SR, Williams JA (1987) Stimulus-secretion coupling in the pancreatic acinus. In: Johnson LR (ed) Physiology of the gastrointestinal tract, 2nd edn. Raven Press, New York, pp $1129-1146$

22. Merritt JE, Hallam TJ (1988) Platelets and parotid acinar cells have different mechanism for agonist-stimulated divalent cation entry. J Biol Chem 263:6161-6164

23. Merritt JE, Jacob R, Hallam TJ (1989) Use of manganese to discriminate between calcium influx and mobilization from internal stores in stimulated human neutrophils. J Biol Chem $264: 1522-1527$

24. Negulescu PA, Machen TE (1988) Intracellular Ca regulation during secretagogue stimulation of the parietal cell. Am J Physiol 254: $\mathrm{C} 130-\mathrm{C} 140$

25. Novak I, Greger R (1988a) Electrophysiological study of transport systems in isolated perfused pancreatic ducts: properties of the basolateral membrane. Pflügers Arch 411:58-68

26. Novak I, Greger R (1988 b) Properties of the luminal membrane of isolated perfused rat pancreatic ducts. Effects of cyclic AMP and blockers of chloride transport. Pflügers Arch 411:546553

27. Padfield PJ, Garner A, Case RM (1989) Patterns of pancreatic secretion in the anaesthetised guinea pig following stimulation with secretin, cholecystokinin octapeptide, or bombesin. Pancreas 4:204-209

28. Schulz I (1987) Electrolyte and fluid secretion in the exocrine pancreas. In: Johnson LR (ed) Physiology of the gastrointestinal tract, 2nd edn. Raven Press, New York pp 1147-1171

29. Stuenkel EL, Machen TE, Williams JA (1988) $\mathrm{pH}$ regulatory mechanisms in rat pancreatic ductal cells. Am J Physiol 254: G925-G930

30. Stuenkel EL, Tsunoda Y, Williams JA (1989) Secretagogue induced calcium mobilization in single pancreatic acinar cells. Biochem Biophys Res Commun 158:863-869

31. Wormsley KG (1969) A comparison of the response to secretin, pancreozymin and a combination of these hormones in man. Scand J Gastroenterol 4:413-417 